\title{
Chemical Composition and Larvicidal Activities of Essential Oils of Medicinal Plants, Artemisia Sieberi and Tanacetum Balsamita Against Malaria Vector, Anopheles Stephensi
}

\author{
Samad Kazempour \\ Tehran University of Medical Sciences \\ Mansoreh Shayeghi \\ Tehran University of Medical Sciences \\ Mohammad Reza Abai \\ Tehran University of Medical Sciences \\ Hassan Vatandoost ( $\sim$ hvatandoost1@yahoo.com ) \\ Tehran University of Medical Sciences \\ Masoumeh Pirmohammadi \\ Tehran University of Medical Sciences
}

\section{Research}

Keywords: Anopheles stephensi, medicinal plants, essential oils, larvicidal

Posted Date: December 1st, 2020

DOI: https://doi.org/10.21203/rs.3.rs-116128/v1

License: (c) (i) This work is licensed under a Creative Commons Attribution 4.0 International License.

Read Full License 


\section{Abstract}

Background: The country is suffering from malaria disease. There are several chemical control of mosquito. Due to resistant of vectors to different pesticides, this research was conducted to measure the chemical components and larvicidal activities of two native plants, Artemisia sieberi and Tanacetum balsamita against Anopheles stephensi.

Materials and methods: Two species of medicinal plants were collected from different localities in in Iran. The plant samples were dried in shaded place and Essential Oils (EO) dried over anhydrous sodium sulfate. The EOs was maintained in the dark sealed vials until conduction larvicidal tests. The maximum storing of EOs was two days. The larvicidal tests were carried out based on the guideline of WHO.

Results: The values of LC50 and LC90 of EOs were 47.9 and $178.8 \mathrm{ppm}$ for Artemisia sieberi. The figure of 26.2and 52.4 ppm was observed for Tanacetum balsamita. The chemical constituents of Tanacetum balsamita and Artemisia sieberi which showed the highest efficacy for larviciding. A total of 39 constituents were isolated from Tanacetum balsamita .The main constituents were Thujone $(52.37 \%)$ and Carvone (26.84\%). Totally 57 constituents were detected in Artemisia sieberi and the main components were : camphor (23.6\%) , 2-Ethyl-3- methyl maleic anhydride (15. 193\%) and, Bombykal $(10.32 \%)$, Ethylbutenol (10.74\%) .

Conclusion: New formulations of plants should be prepared and then evaluated under semi-filed and filed conditions in a malrious areas.

\section{Background}

Mosquitoes are serious public health problem and important pests in tropical and sub-tropical countries. Anopheles stephensi, a highly competent vector of plasmodium is considered a prominent vector of urban malaria [1]. Malaria is the main vector borne diseases worldwide. According to the recent record of World Health Organization, 228 million cases have been reported in 2018 mainly in in African region [2]. Based on the report of Ministry of Health of Iran, less than 89 locally-transmitted cases in 2017 have been reported. The aim of country is to eliminate the disease by 2025 [3]. An. stephensi is the main malaria vector southern parts of country [4]. Vector control by conventional insecticides, personal protection and using repellents from mosquito bites are the best measures of reducing the transmission of these diseases to human. The chemical insecticides have various problems such as, development of resistance, environment pollution and toxic effects on human and non-target organisms [5]. Malaria control in the country is now based on use different insecticides. Distribution of impregnated bed net with permethrin. Using Bacillus thurngiensis and Temephos as larvicide. (CDC, Ministry of Health). According to the WHO (2016) [6] report, drug and insecticide resistance in the malaria parasites and Anopheles species is the main problem. In malarious areas of the world, current vector control measure is not able to control the diseases effectively. Therefore, there is a need to develop and replace these toxic insecticides with new and better ones which are more environmentally safe. In Iran there are some species of malaria 
vectors including: An. stephensi, An. dthali, An. culicifacies, An. fluviatilis, An. superpictus s.l., An. sacharovi, An. maculipennis Complex (Fig. 1) .

\section{Materials And Methods}

Collection, identification and extraction of plants: The plants were collected in East Azerbaijan Province, Northern Iran (Fig.2) . Subsequently they were rapidly transported to the School of Public Health, Tehran University of Medical Sciences

Plant identification: The plant was identified by experts in Department of Plant Sciences, Tehran University (Figs 3,4).

\section{Rearing of mosquito larvae}

Rearing and maintaining mosquito larvae was carried out in the Culicidae insectarium of the School of Public Health Tehran University of Medical Sciences under standard conditions. Early $3^{\text {rd }}-4^{\text {th }}$ instar of larvae were used for larvicidal activities.

\section{Biological tests (larvicidal)}

For larvicidal activities of EO of plants, the standard WHO method was used. Late 3rd - 4th instar larvae were used. In each test, 5 logarithmic concentrations of larvicide were chosen. A total of 4 replicates for each concentration and 2 replicated as control were considered.

\section{Statistical analysis}

The test results of evaluation of EO of plants were calculated after 24hours exposure. The concentrations which cause 50 and $90 \%$ mortality were calculated as LC50 and LC90. Their confidence intervals and the regression line were measured using a regression probit analysis according to the Finney (1971) (7). The percentage mortality was calculated according to Abbot's formula (1925) (8).

\section{Extraction of essential oil of plant}

Faculty of Pharmacology, Tehran University of Medical Sciences were involved in all plant extractions . Essential oils (EOs) of native medicinal plants were hydro distilled in a Clevenger- for 4-6 $\mathrm{h}$ and then anhydrous sodium sulfate were used for drying. The EOs were stored in the dark sealed vials at $4{ }^{\circ} \mathrm{C}$ until starting the experiment.

\section{Plant essential oils analysis}

Chemical composition of plant was analyzed using gas chromatography mass spectrometer. The plants components was performed by comparing their retention times and mass spectra from Wiley library [9].

\section{Results}


The chemical constituents of Tanacetum balsamita and Artemisia sieberi which showed the highest efficacy for larviciding. Results showd a of 39 constituents from T. balsamita. The main constituents were Thujone (52.37\%) and Carvone (26.84\%) respectively. Totally 57 constituents were detected in the essential oil of Artemisia sieberi and the main components were: camphor (23.6\%), 2-Ethyl-3-methyl maleic anhydride (15. 193\%) and, Bombykal (10.32\%), Ethylbutenol (10.74\%) (Table 1,2). The values of LC50 and LC90 of EOs were 47.9 and 178.8 ppm for A. sieberi. The figure of 26.2and 52.4 ppm was observed for T.balsamita (table.3). Probit regression lines of two plants against larvae of An.stephensi is shown in Figs. 5,6.

\section{Discussion}

A total of 500 species of Artemisia are found worldwide. Asia has the greatest concentration of species, 35 species of the genus found in Iran. According to different investigations, It is used for the treatment of different diseases such as malaria, hepatitis, cancer, inflammation, and infections by fungi, bacteria, and viruses [10-13]. In the Middle east, the plant of $A$. sieberi is considered as famous medicinal plant for anthelmintic effects. The extractions of its flowers and leaves were used for treatment of gangrenous ulcers, infectious ulcers, and inflammations. A. sieberi is used as fodder for sheep for increasing of weight. It was used as carminative, to relieve inflammation and abscesses and to prevent leprosy. It is used as pharmacy in traditional medicine. It has anthelmintic, anti-spasmodic, antirheumatic, and antibacterial potency for the treatment of malaria, hepatitis, cancer, inflammation, and menstrual-related disorders [14]. The results of chemical composition analysis of $A$. sieberi essential oils showed the presence of $\beta$-thujone (0-11.6\%), camphor (2.8-42.9\%), 1,8-cineole (0.0-48.7\%) and a-thujone (0-62.1\%). (Mahboubi et al, 2015). A.sieberi extracts showed antimalarial effects against murine malaria [15].

The major constituents of the leaf oil of T.balsamita were bornyl acetate (47.7\%), pinocarvone (27.1\%), camphor (9.3\%) and terpinolene (5.4\%), while the flower oil contained bornyl acetate (55.2\%), pinocarvone (34.2\%), camphor (2.8\%) and terpinolene (2.0\%) and the stem oil contained bornyl actate $(49.2 \%)$, pinocarvone (28\%), camphor (9.5\%) and terpinolene (6\%). [16]. Different local plants were identified and then their extractions were evaluated against An. stephensi in Iran [17].

\section{Conclusion}

Due to high larvicical activities of plants against malaria vector, An.stephensi, it is recommended to make appropriate formulations for these plants and evaluated them under field conditions.

\section{Declarations}

\section{Ethics approval and consent to participate:}

There is not applicable

Consent for publication: 
applicable

\section{Availability of data and material:}

applicable

\section{Competing interests:}

The author declare that there is no conflict of interest

\section{Funding:}

This study was supported by the Ministry of Health and Medical Education of Iran with NIMAD Project Number 971065.

\section{Acknowledgments:}

This study was funded and supported by Tehran University of Medical Sciences (TUMS) and partially by the Ministry of Health and Medical Education of Iran with NIMAD Project Number 971065.

\section{References}

1. World Health Organization. (WHO) 2013.. Malaria entomology and vector control. 2013.

2. World Health Organization (WHO) 2019. World Malaria Report: 2019. Geneva: WHO, pp 232.

3. Vatandoost, H., Raeisi, A., Saghafipour, A., Mikpour, F., Nejati, J. 2019a. Malaria situation in Iran: 2002-2017. Mal J 18(200), 1-7.

4. Vatandoost, H., Shahi, H., Abai, MR., Hanafi-Bojd, A., Oshaghi, M., Zamani, G. 2004 Larval habitats of main malaria vectors in Hormozgan province and their susceptibility to different larvicides. Southeast Asian J Trop Med Public Health 35(2), 22-25.

5. Vatandoost, H., Hanafi Bojd, A 2008 Laboratory evaluation of 3 repellents against Anopheles stephensi in the Islamic Republic of Iran. East Mediterr Health J . 14 (2), 260-267.

6. World Health Organization. (WHO) 2016 Global technical strategy for malaria 2016-2030. pp.35

7. Finny DJ 1971 Probit Analysis.3d Ed.Cambridge University Press.Cambridge,p.333.

8. Abbott, W 1925 A method of computing the effectiveness of an insecticide. J Eco. Entomol 18, 265267 (1925).

9. Pirmohammadi, M., Shayeghi, M., Vatandoost, H., Abaei, M.R, Mohammadi , A., Bagheri, A., Khoobdel, M., Bakhshi, H., Pirmohammadi, M., Tavassoli, M. 2016 Chemical composition and repellent activity of Achillea vermiculata and Satureja hortensis against Anopheles stephensi.. J Arthropod-Borne Dis. 10(2), 201-210.

10. Abad, MJ., Bedoya, LM., Apaza, L., Bermejo, P 2012 . The Artemisia L. genus: a review of bioactive essential oils. Molecules. 17(3), 2542-2566. 
11. Bora, KS., Sharma, A 2011 The genus Artemisia: a comprehensive review. Pharm Biol 49(1), 101-109. (2011).

12. 12.Teixeira da Silva, J.A 2004 Mining the essential oils of the Anthemideae. Afr J Biotech 3(12), 706720.

13. Willcox, M 2009 Artemisia species: From traditional medicines to modern antimalarials and back again. J Altern Complement Med 15(2),101-109.

14. Nigam, M., Atanassova, M., Mishra, A.P., Pezzani, R., Devkota, H.P., Plygun, S., Salehi, B., Setzer, W.N., Sharifi-Rad, J. 2019 Bioactive compounds and health benefits of Artemisia species. Nat Prod Commun. 1-17.

15. Nahrevanian, H., Sheykhkanlooye, B., Kazemi, M., Hajhosseini, R., Soleymani Mashhadi, S., Nahrevanian, S 2012 Antimalarial effects of Iranian flora, Artemisia sieberi on Plasmodium berghei in vivo in mice and phytochemistry analysis of its herbal extracts. Mal Res Treat 1-8.

16. Jaimand, K., Rezaee, M.B 2005 Chemical constituents of essential oils from Tanacetum balsamita L. ssp. balsamitoides (Schultz-Bip.) Grierson. from Iran. J Essent Oil Res 17(5), 1-10.

17. Vatandoost, H., Nikpour, F., Hanafi-Bojd, A.A., Abai, M.R, Khanavi, M., Hajiiakhondi, A., Raesi, A., Nejati, $\mathrm{J} 2019 \mathrm{~b}$ Efficacy of extractions of Iranian native plants against main malaria vector, Anopheles stephensi in Iran for making appropriate formulation for disease control. J. Arthropod-Borne Dis. 13(4), 344-352.

\section{Tables}


Table 1

Chemical components of Tanacetum balsamita

\begin{tabular}{|c|c|c|c|c|}
\hline NO & $\begin{array}{l}\text { tR } \\
\text { (Minutes }\end{array}$ & compound & $\%$ & $\mathbf{R I}$ \\
\hline 1 & 1.774 & Ethanol & 0.478 & - \\
\hline 2 & 2.111 & Hexane & 0.232 & - \\
\hline 3 & 6.503 & cis-Salvene & 0.398 & - \\
\hline 4 & 6.79 & 3,4-Octadiene, 7-methyl- & 0.035 & - \\
\hline 5 & 10.28 & Comphene & 0.080 & 873 \\
\hline 6 & 11.58 & beta-Pinene & 0.079 & 904 \\
\hline 7 & 12.406 & 1-Phenylethanol & 0.140 & 922 \\
\hline 8 & 12.975 & Yomogi alcohol & 1.599 & 933 \\
\hline 9 & 14.002 & p-Cymene & 0.257 & 955 \\
\hline 10 & 14.15 & m-Cymene & 0.188 & 958 \\
\hline 11 & 14.409 & 1,8-Cineole & 1.352 & 963 \\
\hline 12 & 15.711 & gamma-Terpinene & 0.035 & 991 \\
\hline 13 & 19.712 & Thujone & 52.379 & 1067 \\
\hline 14 & 20.046 & 2,5-Octadiene & 1.298 & 1074 \\
\hline 15 & 20.144 & Artemiseole & 0.446 & 1076 \\
\hline 16 & 20.461 & trans-p-2,8-Menthadien-1-ol & 0.242 & 1082 \\
\hline 17 & 20.576 & cis-3,7-Dimethyl-1,3,6-octatriene & 0.260 & 1084 \\
\hline 18 & 20.813 & 6-Nonynoic acid & 0.349 & 1089 \\
\hline 19 & 22.038 & 2,6-Dimethyl-1,5-heptadien-4-ol acetate & 0.909 & 1113 \\
\hline 20 & 22.648 & 3-Cyclohexen-1-ol, 5-methylene-6-(1-methylethenyl)- & 0.208 & 1125 \\
\hline 21 & 23.838 & 2-Nonynoic acid & 1.796 & 1148 \\
\hline 22 & 26.826 & Carvone & 26.844 & 1211 \\
\hline 23 & 27.456 & Carvone oxide & 1.177 & 1229 \\
\hline 24 & 27.932 & Novatone & 1.264 & 1243 \\
\hline 25 & 29.061 & 4-Heptanone & 0.140 & 1277 \\
\hline 26 & 36.012 & Germacrene D & 1.015 & 1403 \\
\hline
\end{tabular}




\begin{tabular}{|c|c|c|c|c|}
\hline NO & $\begin{array}{l}\text { tR } \\
\text { (Minutes }\end{array}$ & compound & $\%$ & $\mathbf{R} \mathbf{I}$ \\
\hline 27 & 36.611 & tau-Muurolol & 0.775 & 1420 \\
\hline 28 & 37.201 & beta-Bisabolene & 1.193 & 1438 \\
\hline 29 & 37.8 & delta-Cadinene & 0.369 & 1455 \\
\hline 30 & 38.074 & alpha-Guaiene & 0.196 & 1463 \\
\hline 31 & 40.471 & Ledene oxide & 0.717 & 1522 \\
\hline 32 & 41.023 & Veridiflorol & 0.151 & 1533 \\
\hline 33 & 42.645 & alpha-Cadinol & 0.783 & 1565 \\
\hline 34 & 43.238 & 5-beta-H,7-beta,10-alpha-Selina-4(19),11-diene & 0.783 & 1576 \\
\hline 35 & 54.213 & n-Hexadecanoic acid & 0.167 & 1867 \\
\hline 36 & 54.519 & 1,2-Longidione & 0.599 & 1874 \\
\hline 37 & 57.967 & 9-Octadecene & 0.175 & 1955 \\
\hline 38 & 58.953 & Isophytol & 0.314 & 1977 \\
\hline 39 & 60.79 & $\begin{array}{l}\text { 4H-Naphtho[2,3-b]pyran-4,6,9-trione, 5,8-dimethoxy-2- } \\
\text { methyl- (CAS) }\end{array}$ & 0.578 & 2020 \\
\hline
\end{tabular}


Table 2

Chemical components of Artemisia sieberi

\begin{tabular}{|c|c|c|c|c|}
\hline NO & $\begin{array}{l}\text { tR (Minut } \\
\text { es }\end{array}$ & compound & $\%$ & $\mathbf{R} \mathbf{I}$ \\
\hline 1 & 1.7 & Ethanol & 0.022 & \\
\hline 2 & 1.765 & Acetone & 0.093 & \\
\hline 3 & 1.975 & 2-Butenal & 0.067 & \\
\hline 4 & 2.084 & Hexane & 0.510 & \\
\hline 5 & 2.631 & Methacrylic acid & 0.485 & \\
\hline 6 & 3.178 & Ethylbutenol & 0.035 & \\
\hline 7 & 3.558 & 2,5-Octadiene & 0.047 & \\
\hline 8 & 4.247 & Butanoic acid, 3-methyl-, methyl ester & 0.043 & \\
\hline 9 & 4.436 & 2-Methyl-3-butenoic acid & 0.070 & \\
\hline 10 & 4.533 & 2-Hexenal & 0.034 & \\
\hline 11 & 6.366 & Ethyl 2-methylbutanoate & 0.061 & \\
\hline 12 & 6.469 & Pentanoic acid, ethyl ester & 0.136 & \\
\hline 13 & 8.833 & 5-Methyl-3-octyne & 0.177 & 837 \\
\hline 14 & 9.053 & alpha-Pinene & 0.202 & 843 \\
\hline 15 & 10.44 & Comphene & 4.142 & 877 \\
\hline 16 & 11.465 & Sabinene & 0.100 & 902 \\
\hline 17 & 11.566 & beta-Pinene & 0.240 & 904 \\
\hline 18 & 12.397 & Ethanol & 0.419 & 921 \\
\hline 19 & 12.932 & Acetone & 0.118 & 0.118 \\
\hline 20 & 13.167 & 2-Butenal & 0.242 & 937 \\
\hline 21 & 13.551 & Hexane & 0.157 & 946 \\
\hline 22 & 14.135 & Methacrylic acid & 0.420 & 958 \\
\hline 23 & 14.73 & Ethylbutenol & 10.748 & 970 \\
\hline 24 & 15.792 & 2,5-Octadiene & 0.272 & 992 \\
\hline
\end{tabular}




\begin{tabular}{|lllll|}
\hline 25 & 17.189 & Butanoic acid, 3-methyl-, methyl ester & 0.063 & 1018 \\
\hline 26 & 18.852 & Linalool & 0.298 & 1051 \\
\hline 27 & 20.978 & Camphor & 23.206 & 1092 \\
\hline 28 & 21.726 & Borneol & 2.680 & 1107 \\
\hline 29 & 22.247 & 4-Terpineol & 0.835 & 1117 \\
\hline 30 & 22.529 & Furfural & 0.103 & 1122 \\
\hline 31 & 22.799 & alpha-Terpineol & 0.269 & 1128 \\
\hline 32 & 22.987 & Piperitol & 0.641 & 1132 \\
\hline 33 & 23.727 & Terpinene-3-ol & 0.921 & 1146 \\
\hline 34 & 24.127 & 2-Cyclohexen-1-ol, 3-methyl-6-(1-methylethyl)-, cis- & 0.109 & 1154 \\
\hline 35 & 24.37 & Isobornyl acetate & 0.090 & 1159 \\
\hline 36 & 24.592 & Davana oil & 0.337 & 1163 \\
\hline 37 & 25.289 & Carvol & 0.630 & 1177 \\
\hline 38 & 25.991 & Piperitone oxide & 1.610 & 1191 \\
\hline 39 & 27.159 & Bornyl acetate & 0.124 & 1221 \\
\hline & & & & \\
\hline
\end{tabular}




\begin{tabular}{|c|c|c|c|c|}
\hline 40 & 31.23 & alpha-Copaene & 0.427 & 1323 \\
\hline 41 & 32.549 & cis-Jasmone & 1.422 & 1345 \\
\hline 42 & 33.159 & trans-Caryophyllene & 0.204 & 1355 \\
\hline 43 & 34.849 & Perilla alcohol & 0.497 & 1382 \\
\hline 44 & 35.929 & Germacrene D & 0.665 & 1400 \\
\hline 45 & 36.587 & Germacrene B & 0.928 & 1420 \\
\hline 46 & 37.825 & Davana ether & 5.029 & 1456 \\
\hline 47 & 38.757 & 2-Ethyl-3-methyl maleic anhydride & 15.193 & 1484 \\
\hline 48 & 39.879 & Bombykal & 3.281 & 1511 \\
\hline 49 & 41.082 & Bombykal & 10.324 & 1534 \\
\hline 50 & 41.496 & Bombykal & 5.984 & 1542 \\
\hline 51 & 42.004 & Humuladienone & 0.309 & 1552 \\
\hline 52 & 43.297 & Isoaromadendrene epoxide & 0.674 & 1578 \\
\hline 53 & 44.523 & 4-[3-Methyl-1-(2-methyl-1-propenyl)-2-butenyl]-3-cyclohexen-1-one & 0.962 & 1603 \\
\hline 54 & 44.971 & cis-Davanone & 1.179 & 1621 \\
\hline 55 & 48.304 & Ascaridole & 1.274 & 1730 \\
\hline 56 & 51.001 & Benzyl salycilate & 0.237 & 1793 \\
\hline 57 & 54.213 & n-Hexadecanoic acid & 0.652 & 1867 \\
\hline
\end{tabular}


Table 3

LC50 and LC90 values of Artemisia sieberi and Tanacetum balsamita against larvae of An.stephensi

\begin{tabular}{|c|c|c|c|c|c|c|c|}
\hline plant & a & $\mathrm{b} \pm \mathrm{SE}$ & $\begin{array}{l}\text { LC50 } \\
\text { (ppm) } \\
\pm_{5}^{ \pm} \% \text { C.L. }\end{array}$ & $\begin{array}{l}\text { LC90 } \\
\text { (ppm) } \\
\frac{ \pm}{95 \% C . L .}\end{array}$ & $\begin{array}{l}\chi 2 \text { (heterog } \\
\text { eneity) }\end{array}$ & $\begin{array}{l}\chi^{2} \\
\text { table } \\
\text { (df) }\end{array}$ & $\begin{array}{l}\mathrm{p}- \\
\text { Value }\end{array}$ \\
\hline Artemisia & -3.7649 & 2.2405 & 41.3 & 141.2 & 40.828 * & 16.26 & 0.001 \\
\hline \multirow[t]{2}{*}{ sieberi } & & $\stackrel{ \pm}{0.222}$ & 47.9 & 178.9 & & $6(3)$ & \\
\hline & & & 55.1 & 248.9 & & & \\
\hline Tanacetum & -6.0418 & 4.2586 & 23.1 & 46.2 & $3.863^{*}$ & 13.27 & 0.001 \\
\hline balsamita & & $\stackrel{ \pm}{0.343}$ & 26.2 & 52.4 & & $7(2)$ & \\
\hline & & & 28.7 & 61.6 & & & \\
\hline
\end{tabular}

Figures 


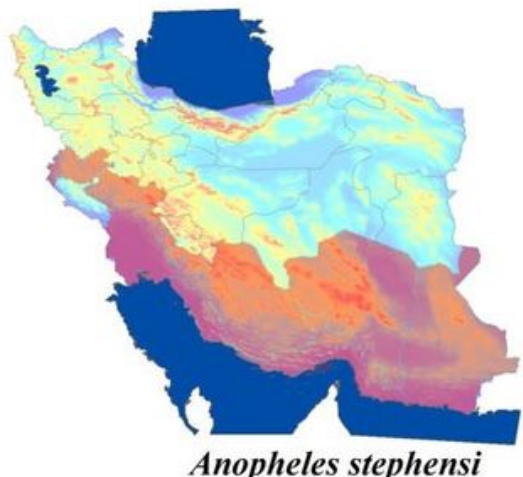

Anopheles stephensi

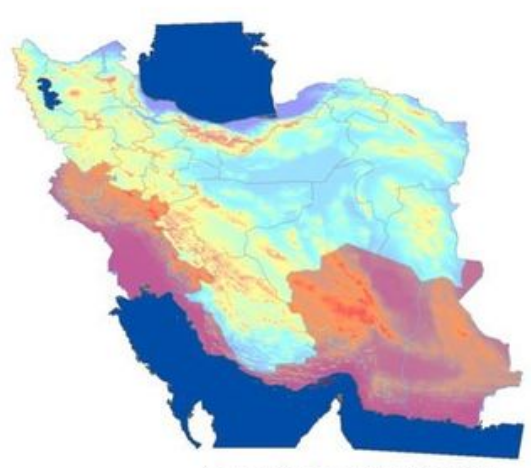

Anopheles fluviatilis
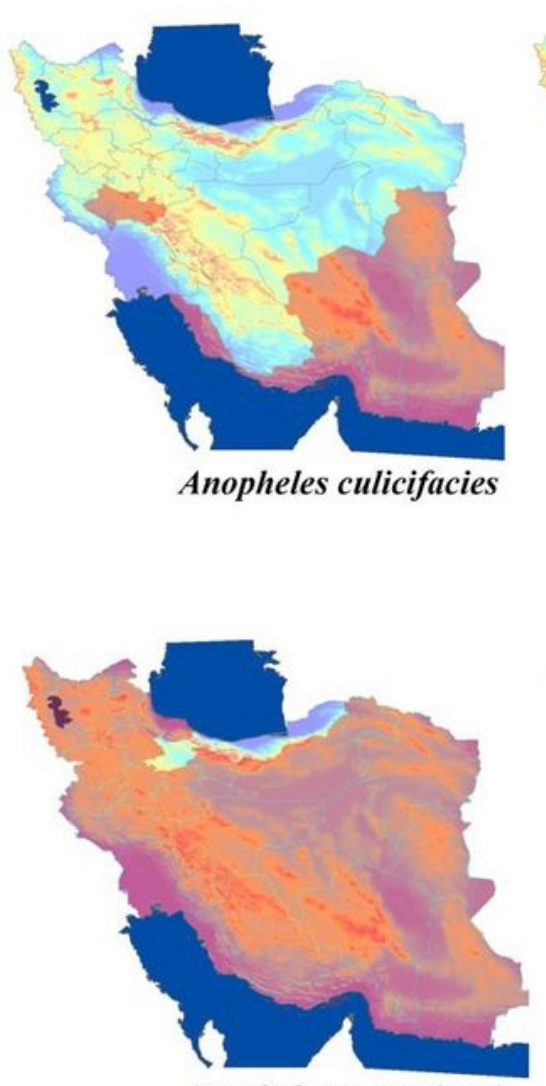

Anopheles superpictus
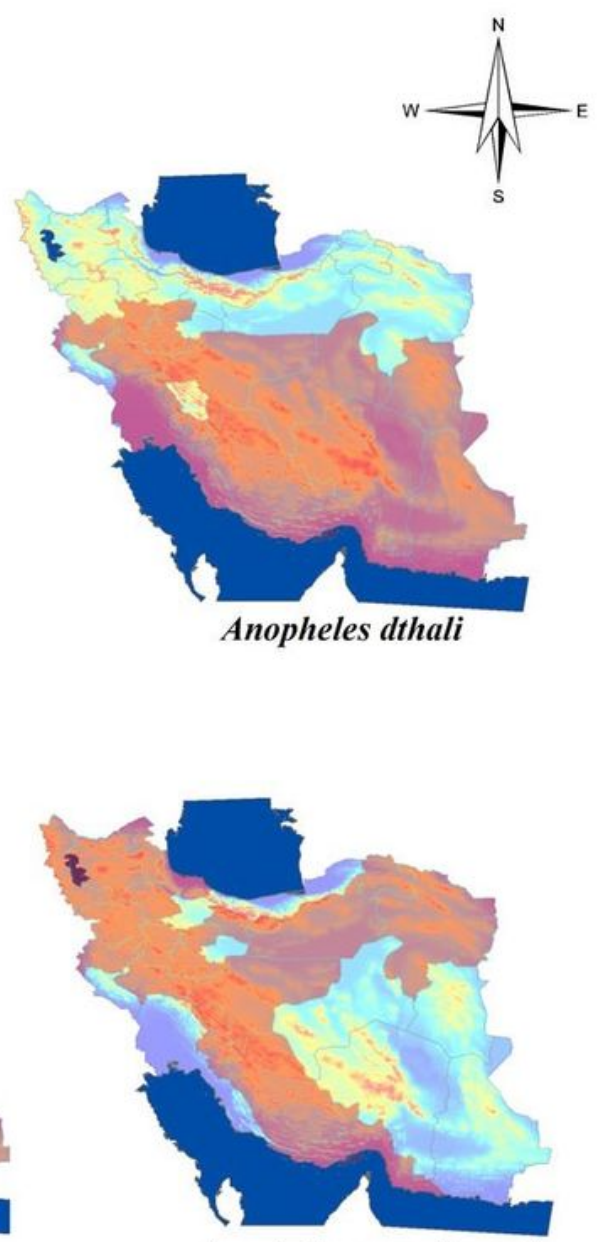

Anopheles maculipennis

Alitiude

High : 5359

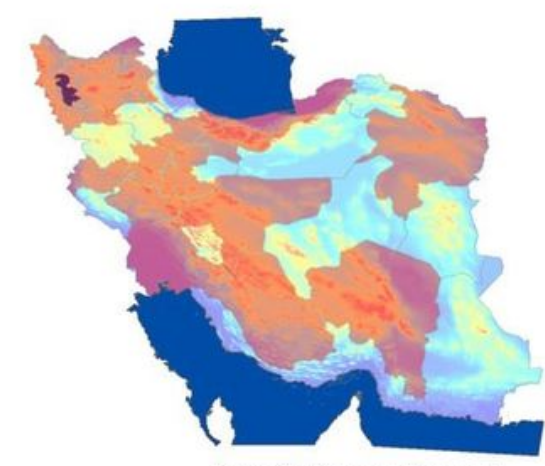

Anopheles sacharovi
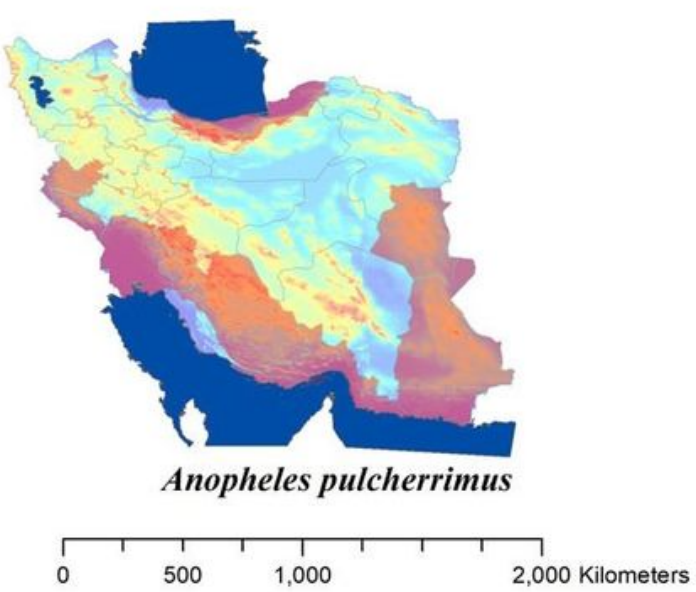

\section{Figure 1}

distribution of malaria vectors in Iran. Note: The designations employed and the presentation of the material on this map do not imply the expression of any opinion whatsoever on the part of Research Square concerning the legal status of any country, territory, city or area or of its authorities, or concerning the delimitation of its frontiers or boundaries. This map has been provided by the authors. 


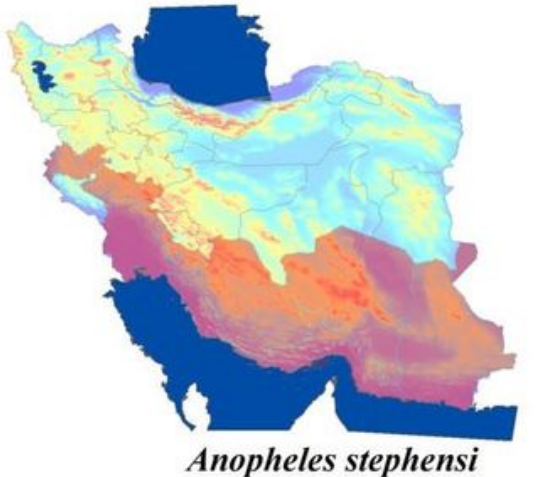

Anopheles stephensi

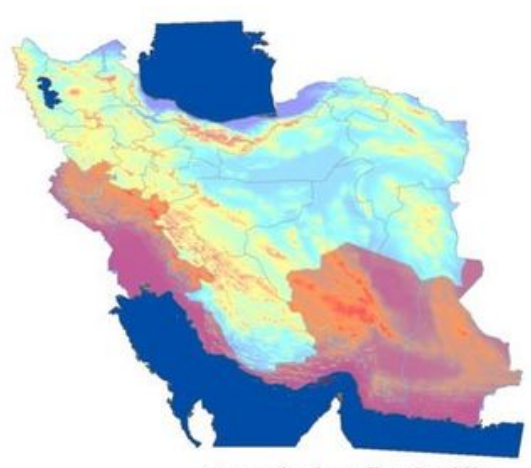

Anopheles fluviatilis
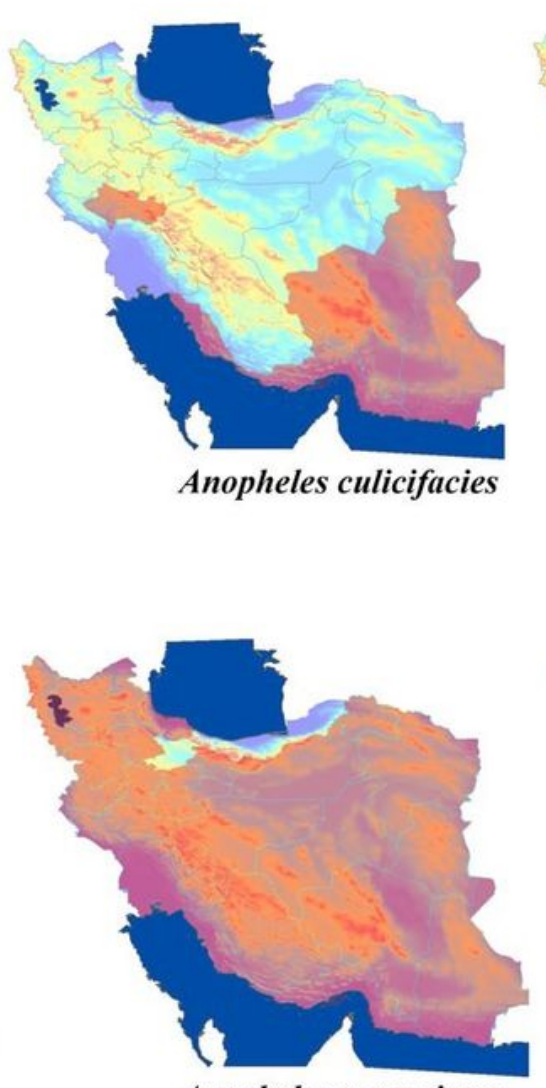

Anopheles superpictus
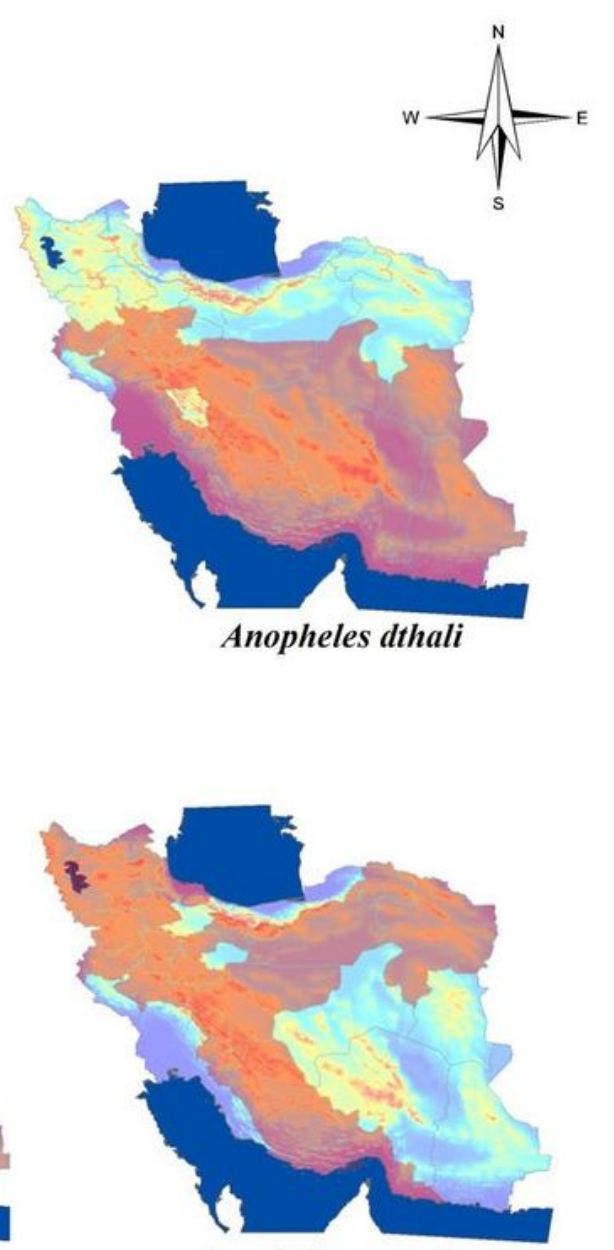

Anopheles maculipennis

Alitiude

High : 5359

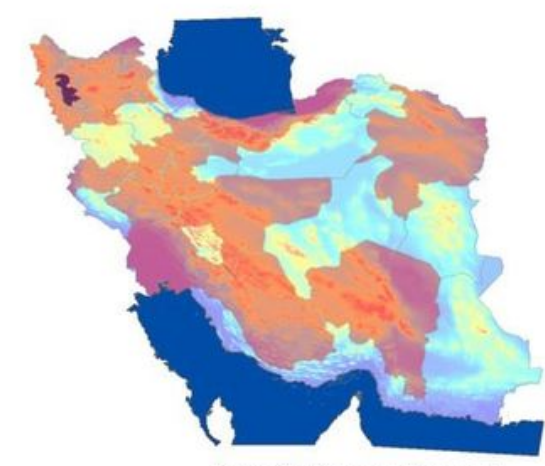

Anopheles sacharovi
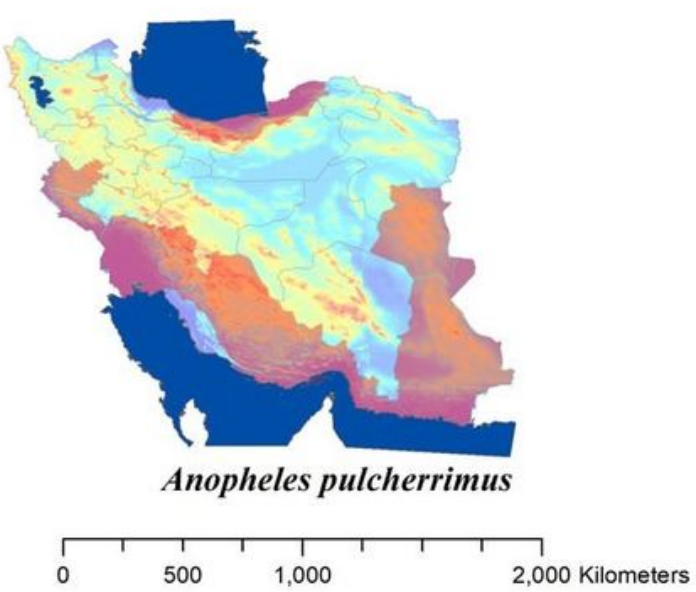

\section{Figure 1}

distribution of malaria vectors in Iran. Note: The designations employed and the presentation of the material on this map do not imply the expression of any opinion whatsoever on the part of Research Square concerning the legal status of any country, territory, city or area or of its authorities, or concerning the delimitation of its frontiers or boundaries. This map has been provided by the authors. 


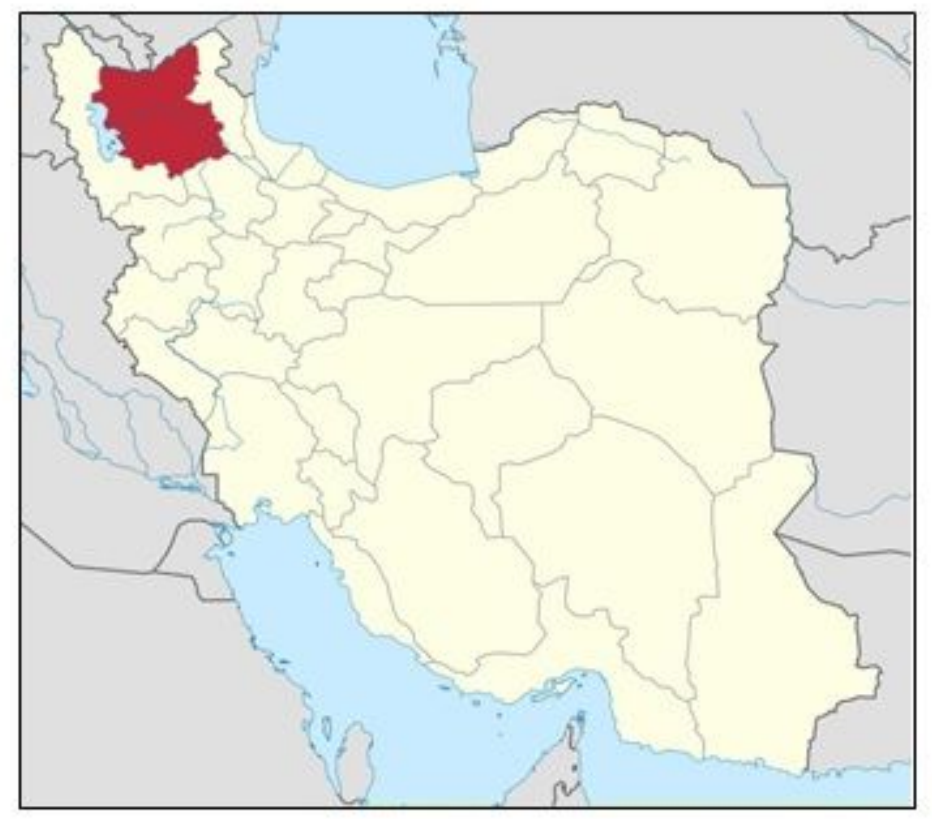

\section{Figure 2}

Map of study area, east Azerbaijan, Iran Note: The designations employed and the presentation of the material on this map do not imply the expression of any opinion whatsoever on the part of Research Square concerning the legal status of any country, territory, city or area or of its authorities, or concerning the delimitation of its frontiers or boundaries. This map has been provided by the authors.

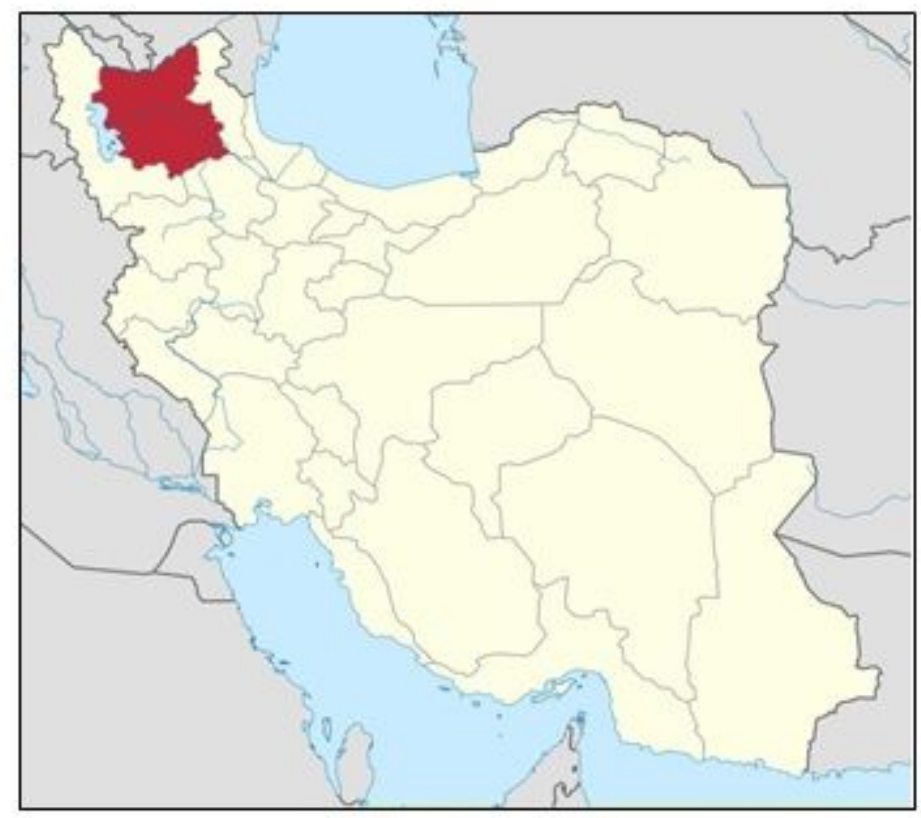

\section{Figure 2}

Map of study area, east Azerbaijan, Iran Note: The designations employed and the presentation of the material on this map do not imply the expression of any opinion whatsoever on the part of Research 
Square concerning the legal status of any country, territory, city or area or of its authorities, or concerning the delimitation of its frontiers or boundaries. This map has been provided by the authors.

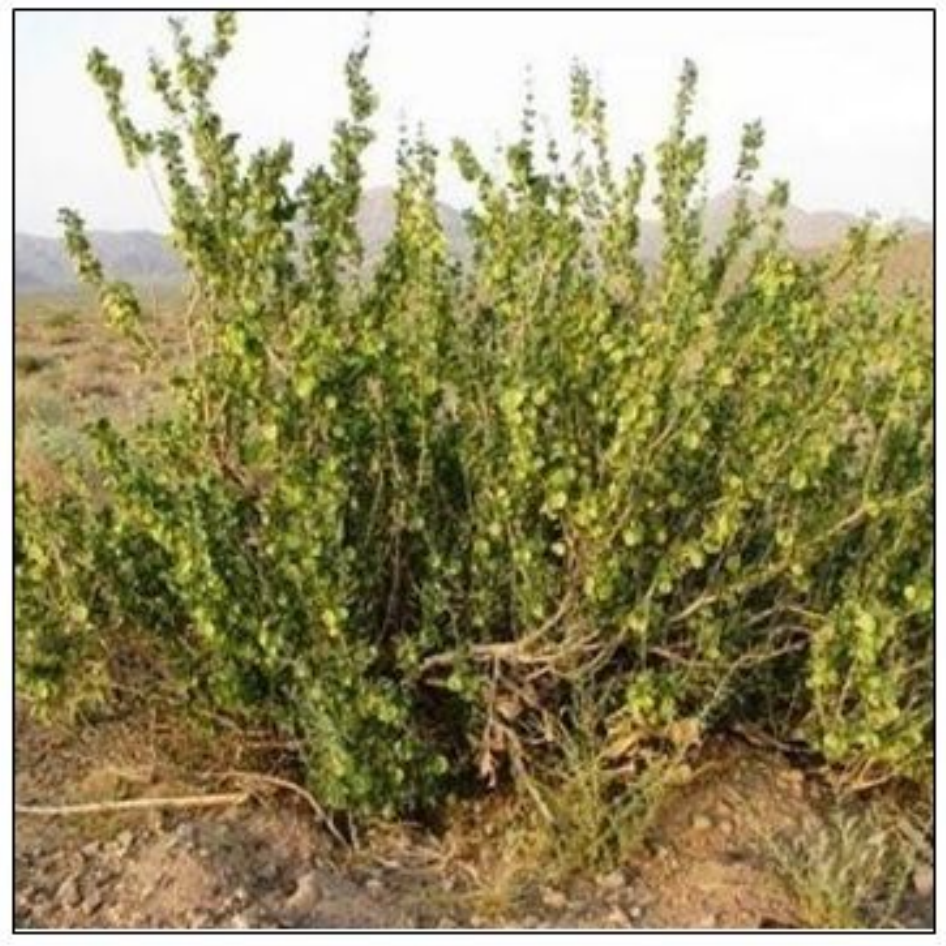

\section{Figure 3}

Artemisia sieberi

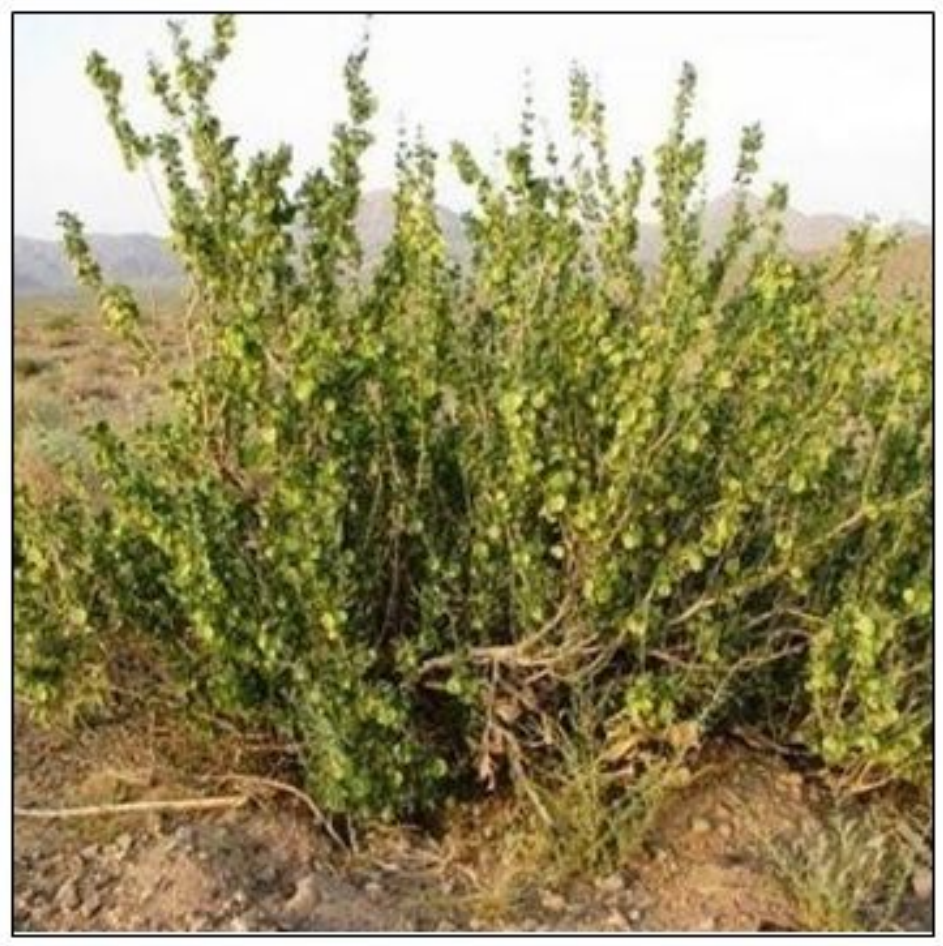

Figure 3 
Artemisia sieberi

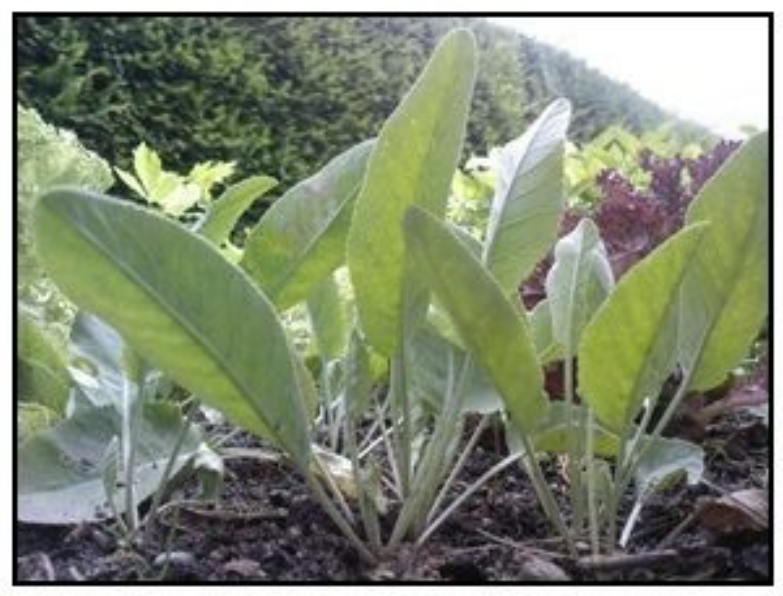

Figure 4

Tanacetum balsamita

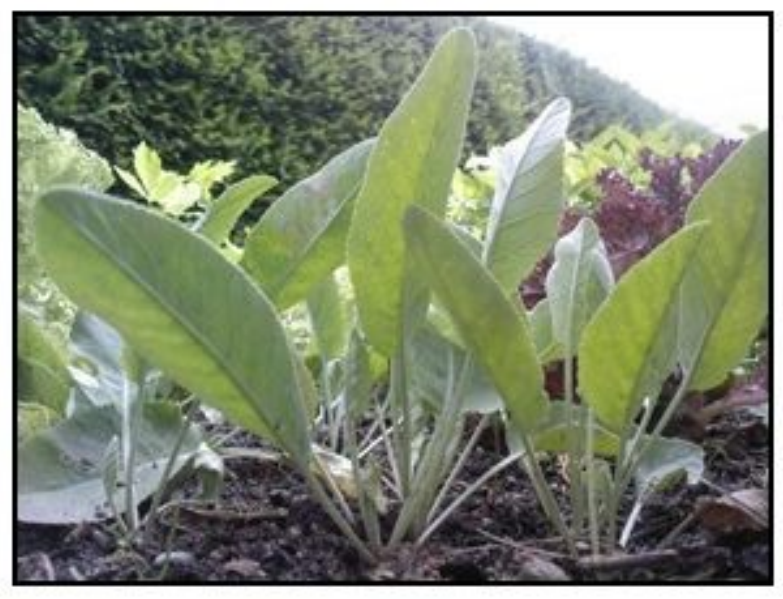

Figure 4

Tanacetum balsamita 


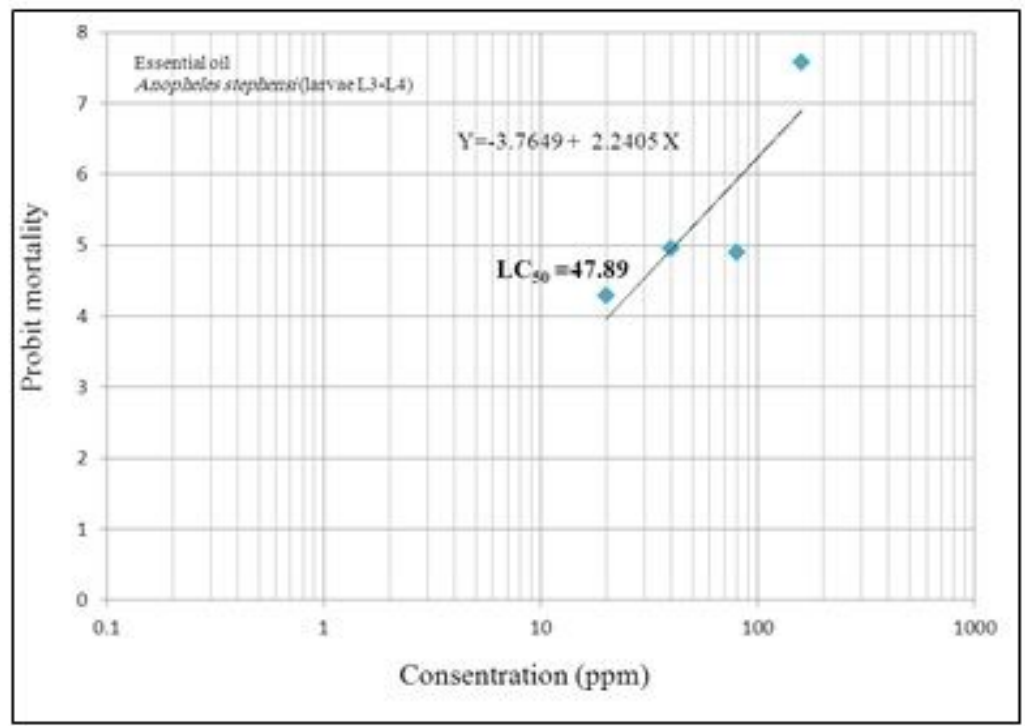

Figure 5

Probit regression line of Artemisia sieberi against larvae of An.stephensi

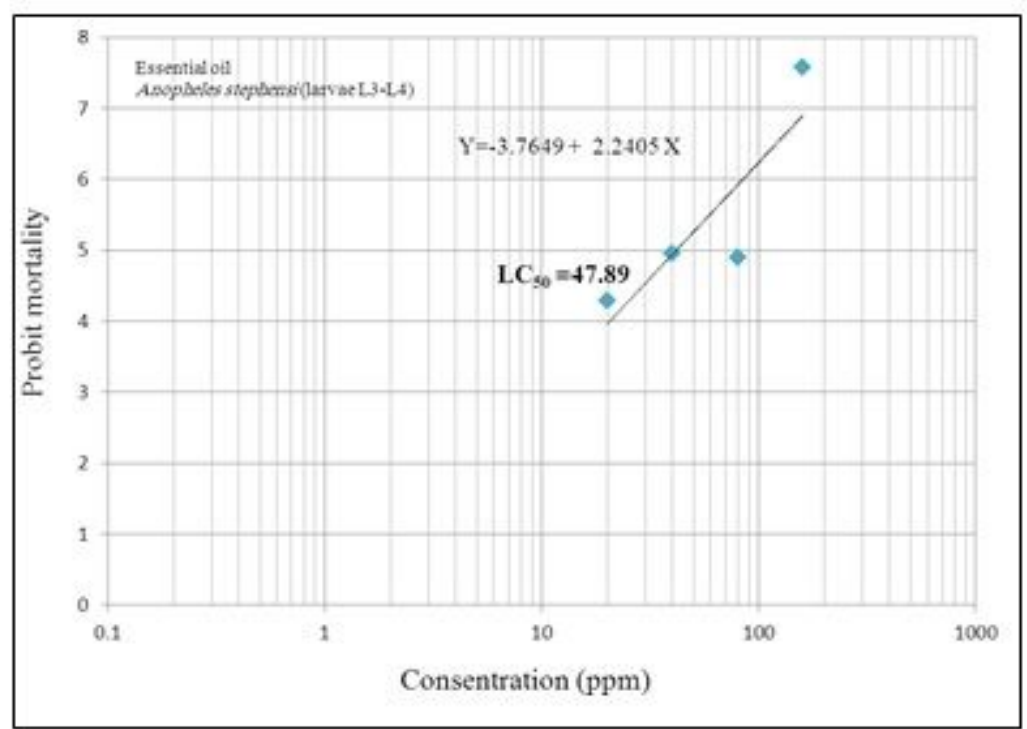

Figure 5

Probit regression line of Artemisia sieberi against larvae of An.stephensi 


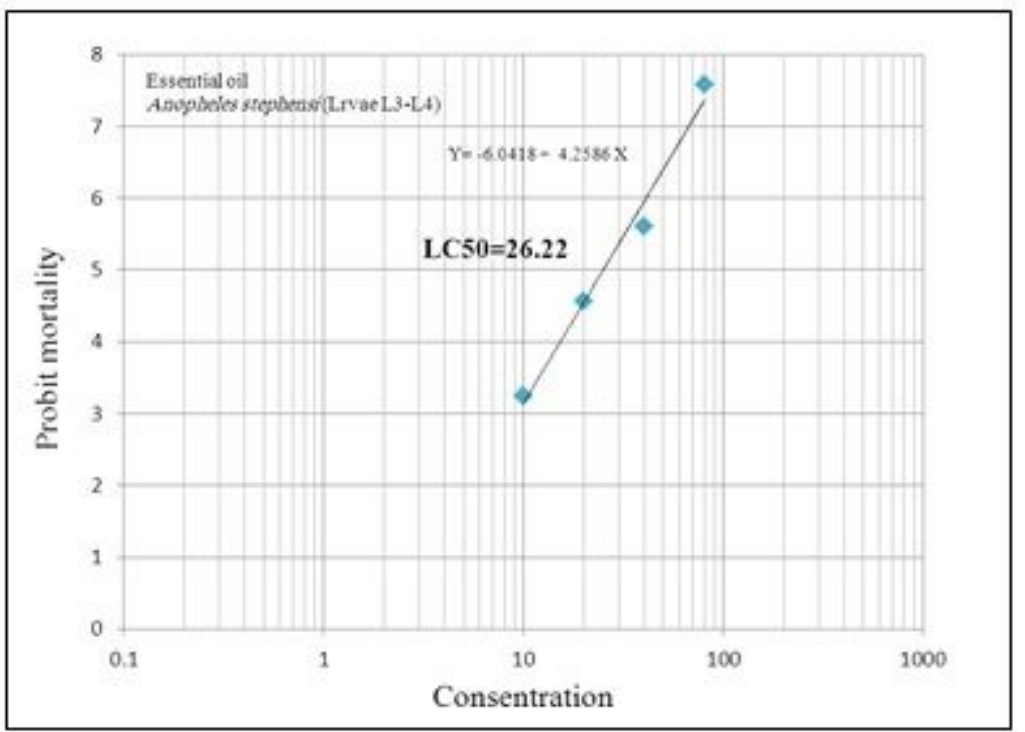

\section{Figure 6}

Probit regression line of Tanacetum balsamita against larvae of An.stephensi

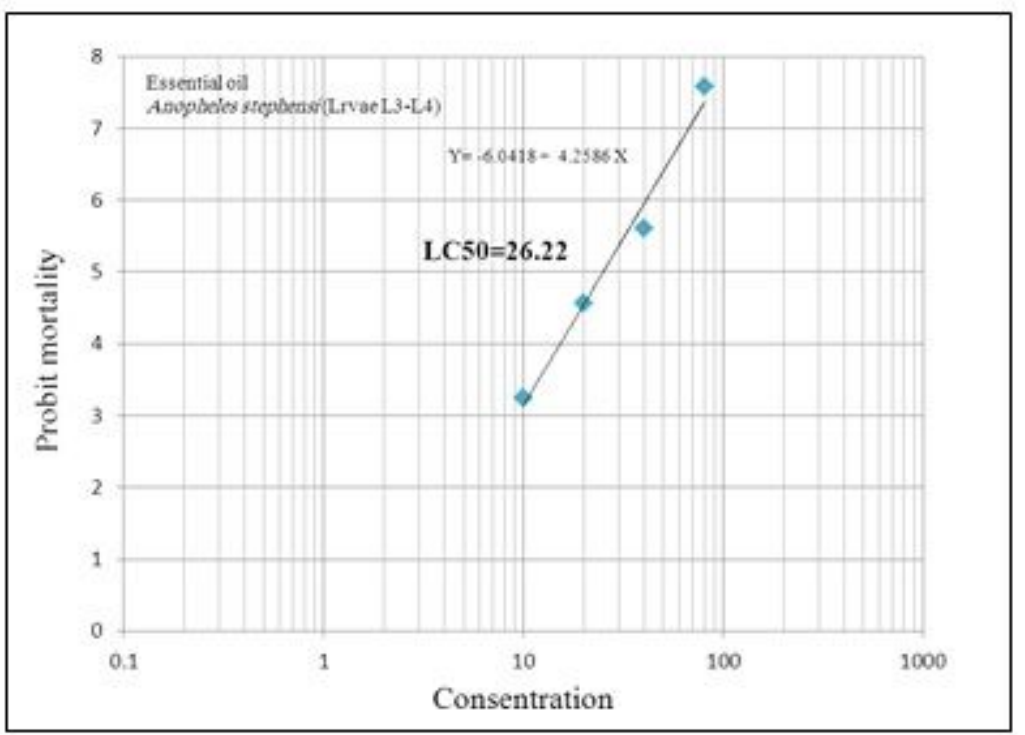

Figure 6

Probit regression line of Tanacetum balsamita against larvae of An.stephensi 